Original Research

\title{
Antimicrobial Resistance of Enterococci from Wild Animals in Slovakia
}

\section{Ludmila Hamarova $^{1}$, Anna Kopcakova ${ }^{1 *}$, Marcela Kocianova-Adamcova ${ }^{2}$, Maria Piknova ${ }^{3}$, Peter Javorsky ${ }^{1}$, Peter Pristas ${ }^{1,3}$}

\author{
${ }^{1}$ Institute of Animal Physiology, Centre of Biosciences of the Slovak Academy of Sciences, \\ Šoltésovej 4-6, Košice 040 01, Slovakia \\ ${ }^{2}$ Faculty of Natural Sciences, Department of Biology and Ecology, Matej Bel University, \\ Tajovského 40, Banská Bystrica 974 01, Slovakia \\ ${ }^{3}$ Institute of Biology and Ecology, Faculty of Science, Pavol Jozef Šafárik University in Košice, \\ Šrobárova 2, Košice 041 54, Slovakia
}

Received: 10 May 2020

Accepted: 13 August 2020

\begin{abstract}
The spread of antibiotic resistant strains is not limited to the clinical environment, but the emergence of resistant bacteria and antibiotic resistance genes in the environment has now become one of the environmental pollution factors. As a model organism for the study of the spread of antibiotic resistance genes, which are a part of digestive tract, we decided to use the genus of Enterococcus isolated from wild living animals in Slovakia to perform screening for the presence of antibiotic resistance. In our work, two hundred and eighty- three isolates were analysed. Among isolates the Enterococcus faecalis (67.1\%) followed by E. hirae (15.9\%), E. faecium (6.4\%), E. casseliflavus (4.2\%), E. durans (3.5\%) and E. mundtii (2.8\%) species dominated. The most frequently resistance to tetracycline $(29.3 \%)$ and erythromycin (15.9\%) was detected. In birds and mammals a similar frequency of resistant enterococci was observed. The differences in antimicrobial resistance to ampicillin and vancomycin were observed. Higher prevalence of ampicillin resistant isolates was detected in birds. On the other hand, vancomycin resistant enterococci were detected in mammals but not in birds. The presence of selected antimicrobial resistance genes was studied by PCR with tet(M) and erm(B) genes being to be the most frequently encountered. Vancomycin resistant enterococci harboured only van(C1) gene. The occurrence of antimicrobial resistance in enterococci from the digestive tract of wild living animals suggests the genetic pollution of environment which could pose a risk for human and animal health.
\end{abstract}

Keywords: enterococci, wild-living animals, antimicrobial resistance, resistance genes

*e-mail:kopcakova@saske.sk 


\section{Introduction}

Antibiotics are among the most successful and the most frequently used drugs in the treatment of diseases in humans and animals. They are naturally occurring substances produced by various microorganisms that can either directly kill other bacteria or stop their growth. Nowadays, antibiotics are losing their efficacy against bacteria and return to the pre-antibiotics era is very real. Antibiotic resistance of enterococci is point of special interest. Enterococci are the facultative anaerobic gram-positive bacteria commonly found in the human and animal gastrointestinal tract and in the environment. These bacteria are considered as indicators of faecal pollution and important nosocomial pathogens. The importance of enterococci is due to their ability to adapt and survive the wide variety of growth conditions, including temperatures from $10^{\circ} \mathrm{C}$ to $45^{\circ} \mathrm{C}$, high and low salts and $\mathrm{pH}$ environments. Among the most distinct examples of enterococcal adaptability is the rapid acquisition of the antibiotic resistance genes. When enterococci become resistant to antibiotics, therapy may be difficult, and the diseases can be fatal. Antimicrobial resistant enterococci are very commonly found not only in the clinical environment [1] but also in farm [2], probably due to antibiotics use as feed additives in agriculture, especially in livestock farming. Waste from farms and hospitals may be contaminated either directly or by genes encoding antimicrobial resistance, which can pollute the environment [3]. The use of antibiotics as growth promoters in animal feed has been banned in the EU since 2006, however, the excessive use of antibiotics seems to persist permanently, covering also other environments and ecological niches that are not subjected to direct human action [4]. In such way, enterococci of animal origin might constitute a human hazard in themselves, but they could act as donors of antimicrobial resistance genes for other pathogenic enterococci as well [5].

The aim of the present study was to examine the distribution of enterococci in faeces of wild living animals in natural environments and to investigate the presence of antimicrobial resistance determinants in these microorganisms in Slovakia.

\section{Material and Methods}

\section{Origin of Samples}

The samples were taken either from animals living in agricultural lowland regions of Slovakia or from high altitude areas (over 1000 meters above sea level) in Tatra National Park and Low Tatras National Park. The animals lived in freedom and it is supposed that they had never received any feed or antimicrobials from humans during their lifetime. As an isolation source of enterococci from bats a sample of guano from Benus village (Banska Bystrica district, Slovakia) was used.
The samples were collected as soon as possible after defecation and transported to the laboratory under aseptic conditions. The average time between defecation and analysis of sample was usually less than 12 hours. Samples were taken from faeces of Eurasian beaver (Castor fiber, 8 isolates), white stork (Ciconia ciconia, 7 isolates), snow vole (Chionomys nivalis, 10 isolates), red deer (Cervus elaphus, 10 isolates), mallard (Anas platyrhynchos, 10 isolates), European pine marten (Martes martes, 10 isolates), red fox (Vulpes vulpes, 10 isolates), brown bear (Ursus arctos, 7 isolates), house mouse (Mus musculus, 10 isolates), common shrew (Sorex araneus, 9 isolates), Eurasian jay (Garrulus glandarius, 9 isolates), tawny owl (Strix aluco, 9 isolates), roe deer (Capreolus capreolus, 10 isolates), alpine marmot (Marmota marmota, 10 isolates), Tatra pine vole (Microtus tatricus, 10 isolates), Tatra chamios (Rupicapra rupicapra tatrica, 10 isolates), European mouflon (Ovis aries musimon, 10 isolates), striped field mouse (Apodemus agrarius, 10 isolates), yellow necked mouse (Apodemus flavicollis, 10 isolates), Ural field mouse (Apodemus uralensis, 10 isolates), common vole (Microtus arvalis, 10 isolates), rook (Corvus frugilegus, 8 isolates), Eurasian jackdaw (Corvus monedula, 10 isolates), rock dove (Columba livia, 10 isolates), European otter (Lutra lutra, 7 isolates), common pheasant (Phasianus colchicus, 10 isolates), black redstart (Phoenicurus ochruros, 10 isolates), fieldfare (Turdus pilaris, 9 isolates), house sparrow (Passer domesticus, 10 isolates) and bat guano (10 isolates). In total, 283 Enterococcus spp. isolates were selected for subsequent analyses.

\section{Isolation and Identification}

Faecal samples or sample of guano (of about $0.5 \mathrm{~g}$ ) were resuspended in sterile PBS solution by intensive mixing for 20 minutes. Aliquots were spread on selective agar medium for enterococci (Bile Esculin Agar, Becton Dickinson, USA) and cultivated under aerobic conditions at $37^{\circ} \mathrm{C}$ for $24 \mathrm{~h}$. Up to 10 morphological relevant isolates from tested individuals were randomly selected for further analysis. Selected isolates were identified by Microflex LT Matrix Assisted Laser Desorption Ionization Time of Flight Mass Spectrometry (MALDI-TOF MS) (Bruker Daltonics, Bremen, Germany). Samples for analysis were prepared by ethanol/formic acid extraction. Procedure was followed according to the manufacturer's instruction. Results were evaluated using the software FlexControlmicroflex 3.0 (Bruker Daltonics) without any user intervention.

\section{Antimicrobial Resistance Analysis}

Antimicrobial resistance to ampicillin, erythromycin, tetracycline, and vancomycin was screened by the disc diffusion method on Mueller-Hinton Agar (Oxoid, UK). Minimal breakpoint concentrations (MIC) of antibiotics 
were based on Clinical and Laboratory Standards Institute guidelines (CLSI 2013) [6]. Differences in resistance between groups of isolates (birds versus mammals) were evaluated using chi-square test with a $5 \%$ significance level [7].

DNA Isolation and Detection of Antibiotic Resistance Genes

Total genomic DNA of enterococcal isolates was extracted by the GenElute Bacterial Genomic DNA Kit (Sigma-Aldrich) from overnight cultures grown in Todd-Hewitt broth. Antibiotic resistance genes were detected using polymerase chain reaction (PCR). The oligonucleotide primer pairs used to amplify the genes $\operatorname{erm}(\mathrm{B}), \operatorname{mef}(\mathrm{A}), \operatorname{tet}(\mathrm{L}), \operatorname{tet}(\mathrm{M}), \operatorname{van}(\mathrm{A}), \operatorname{van}(\mathrm{C1})$ are listed in Table 1. As a positive control in PCR detection of resistance determinants strains according to Stovcik et al. (2008) [8] were used. PCR reactions were performed in Bio-Rad MJ Mini Personal Thermal Cycler (BioRad, USA). DNA samples were tested by agarose gel (1\%) electrophoresis (Bio-Rad, USA).

\section{Results and Discussion}

Five different species of enterococci were identified among 283 Enterococcus spp. isolates from faeces of wild living animals using selective cultivation media followed by MALDI-TOF analysis. This method was found to be reliable for identification of enterococci from both clinical and environmental samples as well [9].

The most common species found were Enterococcus faecalis (67.1\%) and Enterococcus hirae (15.9\%). Less common were Enterococcus faecium (6.4\%), Enterococcus casseliflavus (4.2\%), and Enterococcus durans (3.5\%). Our observations are in line with the findings of Gonçalves et al. (2013) [10], who studied enterococci originating from Iberian lynx and StępieńPyśniak et al. (2018) [9] who studied enterococci from

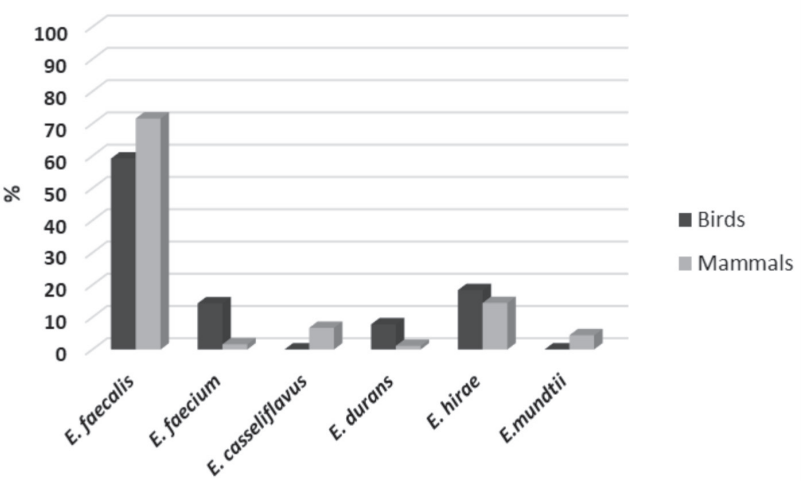

Fig. 1. Distribution of Enterococcus spp. in wild living mammals and birds.

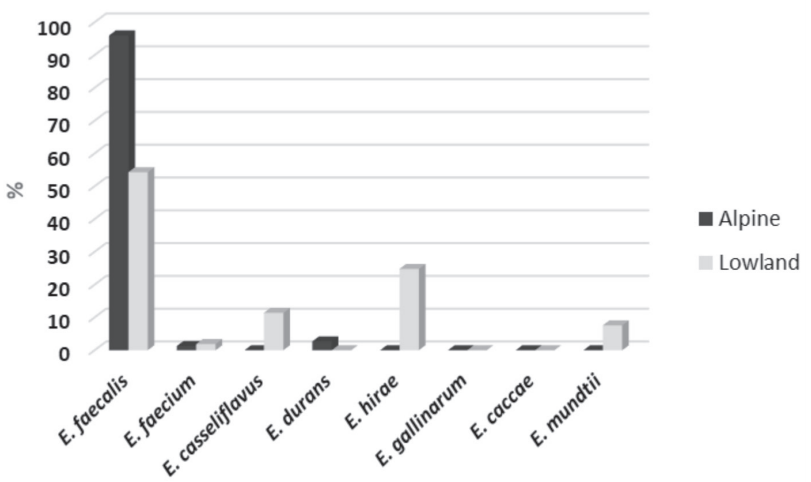

Fig. 2. Distribution of Enterococcus spp. among isolates from alpine and lowland area.

wild birds in Poland. Similarly, the most prevalent species of enterococci from wild rabbits were E. faecalis and E. faecium [11]. The occurrence of Enterococcus spp. in mammals and birds was compared (Fig. 1). Significant differences were detected in the abundance of E. faecium, E. casseliflavus, and E. durans species. Much higher species diversity was observed among isolates from lowland areas when E. faecalis was a

Table 1. Primers used for the detection of antibiotic resistance genes in enterococci.

\begin{tabular}{|c|c|c|c|}
\hline Genes targeted & Sequence $5^{\prime}-3^{\prime}$ & Amplicon size (bp) & References \\
\hline erm $\mathrm{B}$ & $\begin{array}{l}\text { CATTTAACGACGAAACTGGC } \\
\text { GGAACATCTGTGGTATGGCG }\end{array}$ & 424 & Soltani et al., 2000 \\
\hline mefA & $\begin{array}{l}\text { CTATGACAGCCTCAATGCG } \\
\text { ACCGATTCTATCAGCAAAG }\end{array}$ & 1400 & Kastner et al., 2006 \\
\hline tet $\mathrm{M}$ & $\begin{array}{l}\text { GTTAAATAGTGTTCTTGGAG } \\
\text { CTAAGATATGGCTCTAACAA }\end{array}$ & 657 & Nonaka et al., 2007 \\
\hline tet $\mathrm{L}$ & $\begin{array}{l}\text { CATTTGGTCTTATTGGATCG } \\
\text { ATTACACTTGCGATTTCGG }\end{array}$ & 488 & Agresø et al., 2002 \\
\hline $\operatorname{van} \mathrm{A}$ & $\begin{array}{l}\text { GGGAAAACGACAATTGC } \\
\text { GTACAATGCGGCCGTTA }\end{array}$ & 732 & Dutka-Malen et al., 1995 \\
\hline $\operatorname{van} \mathrm{C}-1$ & $\begin{array}{l}\text { GGTATCAAGGAAACCTC } \\
\text { CTTCCGCCATCATAGCT }\end{array}$ & 822 & Dutka-Malen et al., 1995 \\
\hline
\end{tabular}


dominant species detected in faecal samples from alpine animals (Fig. 2).

All identified isolates were tested for the resistance to four antibiotics - ampicillin, erythromycin, tetracycline and vancomycin. Among tested isolates, $36 \%$ exhibited resistance to one or more antibiotics. The most frequent resistance pattern observed was resistance to tetracycline (29.3\%), followed by resistance to erythromycin (15.5\%), to ampicillin $(9.2 \%)$ and to vancomycin (5.7\%). Multi-resistance (resistance to two or more antibiotics) was detected in 56 isolates. The highest frequency of antibiotic resistance was observed in E. faecalis species.

There are very limited data on antibiotic resistant enterococci from wild living animals in Slovakia. Intrinsic resistance to vancomycin in enterococci from chamois detected Jánošková and Kmet' (2004) [12]. On the contrary, Oravcová et al. (2016) [13] described clinically significant enterococci carrying the vanA genes in common raven faeces. Studies on the resistance of enterococci from farm animals and products prepared from farm animals are more frequent [14-16] indicating that antimicrobial resistance is widespread among these bacteria. Generally, there are inconsistent data on occurrence of antibiotic resistance among bacteria from wild animals and the factors influencing the incidence of resistant enterococci are not well understood [17]. Santos et al. (2013) [18] studied the prevalence of antimicrobial-resistant bacteria in wild bird populations and found that the enterococci strains showed high percentages of resistance to tetracycline and erythromycin. Similar findings were reported by Stępień-Pyśniak et al. (2018) [9] who assessed the antimicrobial resistance of $E$. faecalis isolates from wild bird species. Except for lincomycin, the most isolates were resistant to tetracycline and erythromycin. All enterococci strains isolated from meat of wild game animals in study by Guerrero-Ramos et al. 2016 [19] showed multi-resistant phenotype. On the contrary, the study by Semedo-Lemsaddek et al. (2013) [20] showed that $E$. faecalis isolated from Eurasian otter did not carry genes of antibiotic resistance.

The analysis of resistance occurrence revealed that strains originating from birds show higher resistance levels $(64 \%)$ than strains obtained from mammals (53.3 $\%)$. For example, E. faecalis from mallard (30\%) and from Eurasian jay (40\%) were resistant to ampicillin, erythromycin and tetracycline. In general, wild birds are potential vector of bacteria among different environment. Bonnedahl et al. (2009) [21] suggested that wild birds could act as a reservoir of medically important pathogens and resistance genes. The reservoirs of multi-resistant enterococci are considered e.g. common buzzards (Radhouani et al. 2012) [22] and the high incidence of resistant enterococci in wild birds was documented by Klibi et al. (2015) [23]. Similar studies confirm that the use of antibiotics and chemotherapeutic compounds in intensive poultry production has led to expansion of the population of

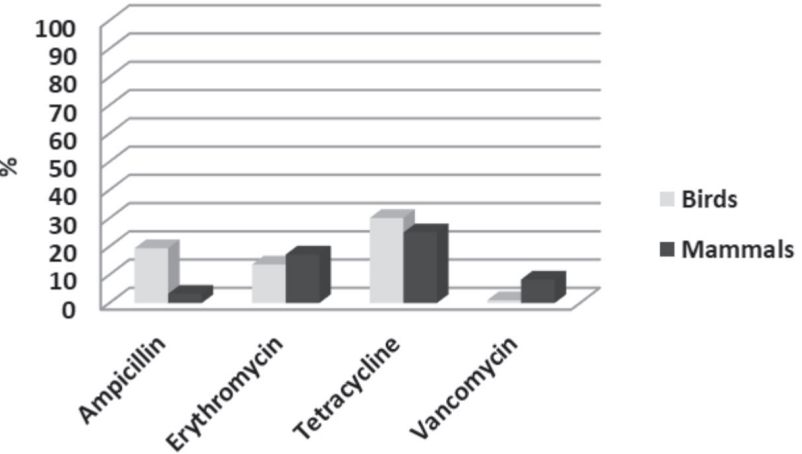

Fig. 3. The incidence of antimicrobial resistance in enterococci from birds and mammals.

multiresistant enterococci in the poultry population of Poland [24]. The dissemination of multiresistant enterococci has become an important cause of zoonotic and nosocomial infections throughout the world [25].

Statistically significant differences between birds and mammals were observed in the incidence of resistance to ampicillin $(p$-value $<0.0001)$ and vancomycin ( $p$-value 0.007) (Fig. 3) when all ampicillin resistant enterococci came from bird samples. In our study all ampicillin resistant isolates were identified as Enterococcus faecalis. Ampicillin resistance occurs in high level of hospital-associated E. faecium isolates, but it is rare in E. faecalis [26]. Abdel-Moein et al. (2017) [27] detected only $3.2 \%$ ampicillin resistant E. faecalis isolated from dogs. Similarly, Santos et al. (2013) [18] observed low level of ampicillin resistance in E. faecalis, E. faecium and E. durans from wild birds. Ampicillin resistant enterococci are reported more frequently in samples from farm animals [28, 29] compared to samples from wild living animals. Zurek and Ghosh (2014) [30] assume that important link for transport of resistant genes among farm animals and wild animals represent insects. Distribution of antimicrobial resistance between different hosts species related to the type of diet was compared in meta-analysis by Vittecoq et al. (2016) [17]. The analysed data indicated

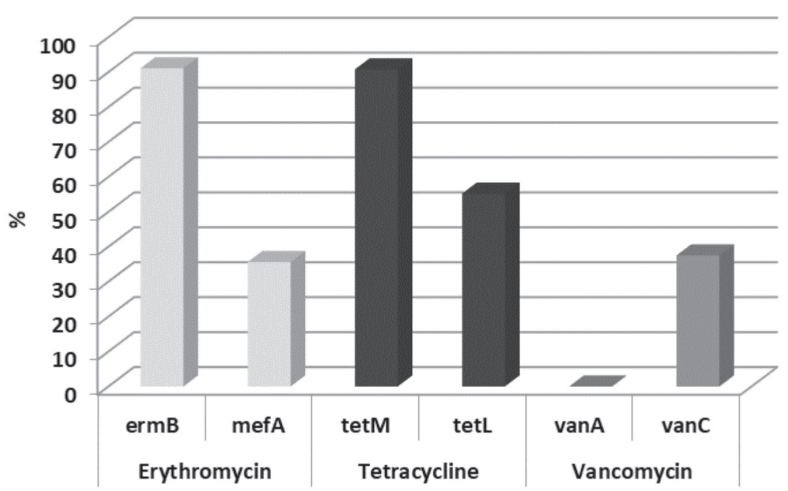

Fig. 4. Occurrence of antibiotic resistance genes in wild living animals. 
that carnivores and omnivores are probably most at risk in antibiotic resistance transfer. Our results supported this hypothesis as the highest level of antimicrobial resistance was detected in omnivores compared to other nutrition type animals.

The presence of antibiotic resistance genes was tested by PCR. The tet $\mathrm{M}$ gene was found as predominant $(90.8 \%)$ in tetracycline resistant isolates, while the tet $\mathrm{L}$ gene was confirmed in $55.2 \%$ isolates (Fig. 4). The combination of tet $\mathrm{M}$ and tet $\mathrm{L}$ was detected in $52.9 \%$ isolates. Enterococci from broiler chicken harboured both tet $\mathrm{M}$ and tet $\mathrm{L}$ gene at similar high frequency (68.1\%) (Diarra et al. 2010) [31] and Rahman et al. (2015) [32] found tetracycline resistant bacteria (harbouring tet $\mathrm{M}$ gene) in faecal microbial community of Adélie penguin in Antarctica.

The erm $\mathrm{B}$ gene was the most prevalent resistance determinant found in erythromycin-resistant isolates. The mefA gene, coding for a macrolide efflux, was found in $35.6 \%$ isolates. The co-occurrence of the erm $\mathrm{B}$ and mefA genes was detected in $33.3 \%$ isolates. For comparison all clinical enterococcal isolates with high level of resistance to erythromycin carried the erm $\mathrm{B}$ gene but no isolate carried mefA gene [33]. Similar results were documented in sheep [5] where mefA gene was present in 3 of $14(21.4 \%)$ isolates from birds and in 13 of $30(43.3 \%)$ isolates from mammals.

Using PCR no vanA positive vancomycin resistant isolates were found in tested collection of isolates. Oravcová et al. (2014) [34] detected vanA gene in 2.5\% of enterococci isolates from wild American crows and Mallon et al. (2002) [35] observed vanA genotype in $E$. faecium isolated from woodmice (4.6\%) and badgers (1.2 \%). However, $37.5 \%$ isolates, identified as $E$. faecalis and E. hirae, were positive for van $\mathrm{C} 1$ gene. All these isolates were correctly identified by MALDI TOF MS with score values of $>2.30$ what indicates highly probable species identification. While VanC1 phenotype is common in E. faecalis, it was found in E. hirae as well [36]. On the other hand, Drobni et al. (2009) [37] collected faecal samples from birds at the sites with no or low human population and detected vancomycin resistant enterococci isolates.

All isolates from high altitude areas were taken from mammals from the territories of two Slovak national parks. Surprisingly, much higher frequency of tetracycline and erythromycin resistance was observed between enterococci isolated from mammals in Tatra National Park (TANAP) compared to Low Tatras National Park (NAPANT) despite both national parks cover alpine parts of mountains around river Vah with similar climatic conditions. One of the possible explanations for the differences in antimicrobial resistance occurrence are differences in anthropogenic influences (tourism). Recent analyses of bacterial communities from two localities in Tatra National Park suggested different bacterial diversity, which corresponds probably to lower intensity of visitors and less anthropogenic impact [38].
A study of the occurrence of antimicrobial resistance in bacteria is needed not only in hospitals but also in farm environment and nature to understand the role of wild living animals in spreading resistant bacteria and antibiotic resistance genes in the environment.

\section{Conclusions}

We studied the occurrence of antimicrobial resistance in enterococci in wild animals in Slovakia. The frequency of resistance of enterococci from the digestive tract of wild living animals suggested the genetic pollution of environment and represents a risk for human and animal health. Is therefore necessary to observe and study the spread of antimicrobial resistance in enterococci in the environment.

\section{Acknowledgements}

This work was supported by the Grant Agency APVV-16-0171.

\section{Conflict of Interest}

The authors declare no conflict of interest.

\section{References}

1. SALEM-BEKHIT M.M., MOUSSA I.M., MUHARRAM M.M., ALANAZY F.K., HEFNI H.M. Prevalence and antimicrobial resistance pattern of multidrug-resistant enterococci isolated from clinical specimens. Indian journal of medical microbiology. 30 (1), 44, 2012.

2. ŠEPUTIENE V., BOGADAITE A., RUŽAUSKAS M., SUŽIEDELIENE E. Antibiotic resistance genes and virulence factors in Enterococcus faecium and Enterococcus faecalis from diseased farm animals: pigs, cattle and poultry. Polish journal of veterinary sciences. 15 (3), 431, 2012.

3. CABELLO F.C. Heavy use of prophylactic antibiotics in aquaculture: a growing problem for human and animal health and for the environment. Environmental microbiology reports. 8 (7), 1137, 2006.

4. NOWAKIEWICZ A., ZIEBA P., GNAT S., TROŚCIANCZYK A., OSIŃSKA M., ŁANGOWSKI D., KOSIOR-KORZECKA U., PUZIOUZIO I. A significant number of multi-drug resistant Enterococcus faecalis in wildlife animals; long-term consequences and new or known reservoirs of resistance? The Science of the Total Environment. t 705, 135830, 2020.

5. HAMMERUM A.M. Enterococci of animal origin and their significance for public health, Clinical Microbiology and Infection. 18 (7), 619-625, 2012.

6. CLSI. Clinical Laboratory Standards Institute. Performance standards for antimicrobial susceptibility testing. Wayne, PA $23^{\text {th }}$ Informational Supplement M:100-S20, 2013. ISBN 1-56238-865-7.

7. Statistica 7.1, Statsoft s.r.o., Czech Republic, 2005. 
8. STOVCIK V., JAVORSKY P., PRISTAS P. Antibiotic resistance patterns and resistance genes in enterococci isolated from sheep gastrointestinal tract in Slovakia. Bulletin of the Veterinary Institute in Pulawy. 52, 53, 2008.

9. STEPIEN-PYSNIAK D., HAUSCHILD T., NOWACZEK A., MAREK A., DEC M. Wild birds as a potential source of known and novel multilocus sequence types of antibiotic resistant Enterococcus faecalis. Journal of wildlife diseases. 54 (2), 219, 2018.

10. GONCALVES A., IGREJAS G., RADHOUANI H., SANTOS T., MONTEIRO R., PECHECO R., ALCAIDE E., ZORILlA I., SERRA R., TORRES C., POETA P. Detection of antibiotic resistant enterococci and Escherichia coli in free range iberian Lynx (Lynx pardinus). The Science of the total environment. 456-457, 115-119, 2013.

11. SILVA N., IGREJAS G., FIGUEIREDO N., GONÇALVES A., RADHOUANI H., RODRIGUES J., POETA, P. Molecular characterization of antimicrobial resistance in enterococci and Escherichia coli isolates from European wild rabbit (Oryctolagus cuniculus). Science of The Total Environment. 408, 4871, 2010.

12. JÁNOŠKOVÁ A., KMEŤ V. Vancomycin resistance genes in Enterococcus spp. Strains isolated from alpine accentor and chamois. Acta Veterinaria Brno. 73, 211, 2004.

13. ORAVCOVÁ V., HADELOVÁ D., LITERAK I. Vancomycin-resistant Enterococcus faecium with vanA gene isolated for the first time from wildlife in Slovakia. Veterinary Microbiology. 194, 43, 2015.

14. DRAHOVSKÁ H., SLOBODNÍKOVÁ L., KOCÍNOVÁ D., SEMAN M., KONČEKOVÁ R., TRUPL J., TURŇA J. Antibiotic resistance and virulence factors among clinical and food enterococci isolated in Slovakia. Folia Microbiologica. 49, 763-768, 2004.

15. BELICOVÁ A., KRIŽKOVÁ L., KRAJČOVIČ L., JURKOVIČ D., SOJKA M., EBRINGER L., DUŠINSKÝ R. Antimicrobial susceptibility of Enterococcus species isolated from Slovak bryndza cheese. Folia Microbiologica. 52, 115, 2007.

16. DUCKOVÁ V., ČANIGOVÁ M., KROČKO M., LAVOVÁ M. Antibiotic susceptibility and biofilm-forming capacity of enterococci isolated from food of animal origin. Medycyna Weterynaryjna. 70, 36, 2014.

17. VITTECOQ M., GODREUIL S., PRUGNOLLE F., DURAND P., BRAZIER L. RENAUD N., ARNAL A., ABERKANE S., JEAN-PIERRE H., GAUTHIER-CLERC M., THOMAS F., RENAUD F. Antimicrobial resistance in wildlife. Journal of Applied Ecology. 53, 519, 2016.

18. SANTOS T., SILVA., IGREJAS G., RODRIGUES P., MICAEL J., RODRIGUES T. RESENDERS R., GONCALVES A., MARINHO C., GONCALVES D., CUNHA R., POETA P. Dissemination of antibiotic resistant Enterococcus spp. and Escherichia coli from wild birds of Azores Archipelago. Anaerobe. 24, 25, 2013.

19. GUERRERO-RAMOS E., CORDERO J., MOLINAGONZÁLES D., POETA P., IGREJAS G., ALONSOCALLEJA C., CAPITA R. Antimicrobial resistance and virulence genes in enterococci from wild game meat in Spain. Food Microbiology. 53, 156, 2016.

20. SEMEDO-LEMSADDEK T., NÓBREGA S.C., RIBEIRO T., PEDROSO N.M., SALES-LUIS T., LEMSADDEK A., TENREIRO R., TAVARES L., VILELA C.L., OLIVEIRA M. Virulence traits and antibiotic resistance among enterococci isolated from Eurasian otter (Lutra lutra). Veterinary Microbiology. 163, 378, 2013.
21. BONNEDAHL J., DROBNI M., GRAUTHIER-CLERC M., HERNANDEZ J., GRANHOLM S., KAYSER Y., MELHUS A., KAHLMETER G., WALDEMSTROM J., JOHANSSON A., OLSEN B. Dissemination of Escherichia coli with CTX-M type ESBL between humans and yellow-legged gulls in the south of France. PLoS ONE. 4 (6), e5958, 2009.

22. RADHOUANI H., POETA P., GONCALVES A., PACHECO R., SARGO R., IGREJAS G. Wild birds as biological indicator of environmental pollution: antimicrobial resistance patterns of Escherichia coli and enterococci isolated from common buzzards (Buteo buteo). Journal of Medical Microbiology. 61 (Pt6), 837, 2012.

23. KLIBI N., AMOR I.B., RAHMOUNI M., DZIRI R., DOUJA G., SAID L.B., LOZANO C., ABDELLATIF B., SALMA K.B., MANSOURI R., TORRES C. Diversity of species and antibiotic resistance among fecal enterococci from wild birds in Tunisia. Detection of vanA-containing Enterococcus faecium isolates. European Journal of Wildlive Research. 61, 319, 2015.

24. STEPIEŃ-PÝSNIAK D., MAREK A., BANACH T., ADASZEK Ł., PYZIK E., WILCZYŃSKI J., WINIARCZYK. Prevalence and antibiotic resistance of Enterococcus strains isolated from poultry. Acta veterinaria Hungarica. 64 (2), 148, 2016.

25. HASAN K.A., ALI S.A., REHMAN M., BIN-ASIF H., ZAHID S. The unravelled Enterococcus faecalis zoonotic superbugs: Emerging multiple resistant and virulent lineages isolated from poultry environment. Zoonoses Public Health. 65 (8), 921, 2018.

26. ARIAS C.A., MURRAY B.E. The rise of Enterococcus: beyond vancomycin resistance. Nature reviews. Microbiology. 10 (4), 266, 2012.

27. ABDEL-MOEIN K.A., EL-HARIRI M.D., WASFY M.O., SAMIR A. Occurence of ampicillin-resistant Enterococcus faecium carrying esp gene in pet animals: An upcoming threat for pet lovers. Journal of Global Antimicrobial Resistance. 9, 115, 2017.

28. BERTELLONI F., SALVADORI C., MONI A., CERRI D., MANI P., EBANI V.V. Antimicrobial resistance in Enterococcus spp. Isolated from laying hens of backyard poultry flocks. Annals of Agricultural and Environmental Medicine. 22 (4), 665, 2015.

29. NOVAIS C., FREITAS A.R., SILVEIRA E., ANTUNES P., SILVA R., COQUE T.M. PEIXE L. Spread of multidrug-resistant Enterococcus to animals and humans: an underestimated role for the pig farm environment. The Journal of Antimicrobial Chemotherapy. 68 (12), 2746, 2013.

30. ZUREK L., GHOS A. Insect represent a link between food animal farms and the urban environment for antibiotic resistance traits. Applied and Environmental Microbiology. 80 (12), 3562, 2014.

31. DIARRA M.S., REMPEL H., CHAMPAGNE J., MASSON L., PRITCHARD J., TOPP E. Distribution of antimicrobial resistance and virulence genes in Enterococcus spp. and characterization of isolates from broiler chicken. Applied and Environmental Microbiology. 76 (24), 8033, 2010.

32. RAHMAN M.H., SAKAMOTO K.Q., KITAMURA S.I., NONAKA L., SUZUKI S. Diversity of tetracyclineresistant bacteria and resistance gene tet(M) in fecal microbial community of Adélie penguin in Antarctica. Polar Biology. 38, 1775, 2012.

33. REYES J., HIDALGO M., DÍAZ L., RINCÓN S., MORENO J., VANEGAS N., CASTANEDA E., ARIAS 
C.A. Characterization of macrolide resistance in Grampositive cocci from Colombian hospitals: a countrywide surveillance. International Journal of Infectious Diseases. 11, 329, 2007.

34. ORAVCOVÁ V., ZUREK L., TOWNSEND A., CLARK A.B., ELLIS J.C., CIZEK A., LITERAK I. American crows as carriers of vancomycin-resistant enterococci with vanA gene. Environmental Microbiology. 16 (4), 939, 2014.

35. MALLON D.J.P., CORKILL J.E., HAZEL S.M., WILSON J.S., FRENCH N.P., BENNETT M. ANTHONY C. Excretion of vancomycin-resistant enterococci by wild mammals. Emerging Infectious Diseases. 8 (6), 636, 2002. ISSN: 1080-6059.

36. SKOWRON K., JELENSKA A., PALUSZAK Z., SZALA B. Prevalence and distribution of VRE (vancomycin resistant enterococci) and VSE (vancomycin susceptible enterococci) strains in the breeding environment. Annals of Agricultural and Environmental Medicine. 23 (2), 231, 2016.

37. DROBNI M., BONNEDAHL J., HERNANDEZ J., HAEMING P., OLSEN B. Vancomycin-resistant enterococci, Point Barrow, Alaska, USA. Emerging Infectious Diseases. 15 (5), 838, 2009.

38. JÚDOVÁ J., LACUŠOVÁ V., KVASNOVÁ S., ŠVAJDA J. Microbial investigation of recreation effects on water and soil in the Tatra National Park. Ekologia 36, 290, 2017.
39. SOLTANI M., BEIGHTON D., PHILPOTT-HOWARD J., WOODFORD N. Mechanisms of 330 resistance to quinupristin-dalfopristin among isolates of Enterococcus faecium 331 from animals, raw meat, and hospital patients in Western Europe. Antimicrobial Agents and Chemotherapy. 44, 433, 2000.

40. KASTNER S., PERRETEN V., BLEULER H., HUGENSCHMIDT G., LACROIX C., MEILE L. Antibiotic susceptibility patterns and resistance genes of starter cultures and probiotic bacteria used in food. Systematic and Applied Microbiology. 29, 145, 2006.

41. NONAKA L., IKENO K., SUZUKI S. Distribution of tetracycline resistance gene, tet(M), in Gram-positive and Gram-negative bacteria isolated from sediment and seawater at a coastal aquaculture sites in Japan. Microbes and Environments. 22, 335, 2007.

42. AGRES $\varnothing$ Y., BOGO L., JENSEN L.B., GIVSKOV M., ROBERTS M.C. The identification of a tetracycline resistance gene tet(M), on a Tn916-like transposon, in the Bacillus cereus group. FEMS Microbiology Letters. 214 (2), 251, 2002.

43. DUTKA-MALEN S., EVERS S., COURVALIN P. Detection of glycopeptide resistance genotypes and identification to the species level of clinically relevant enterococci by PCR. Journal of Clinical Microbiology. 33, 24, 1995. 